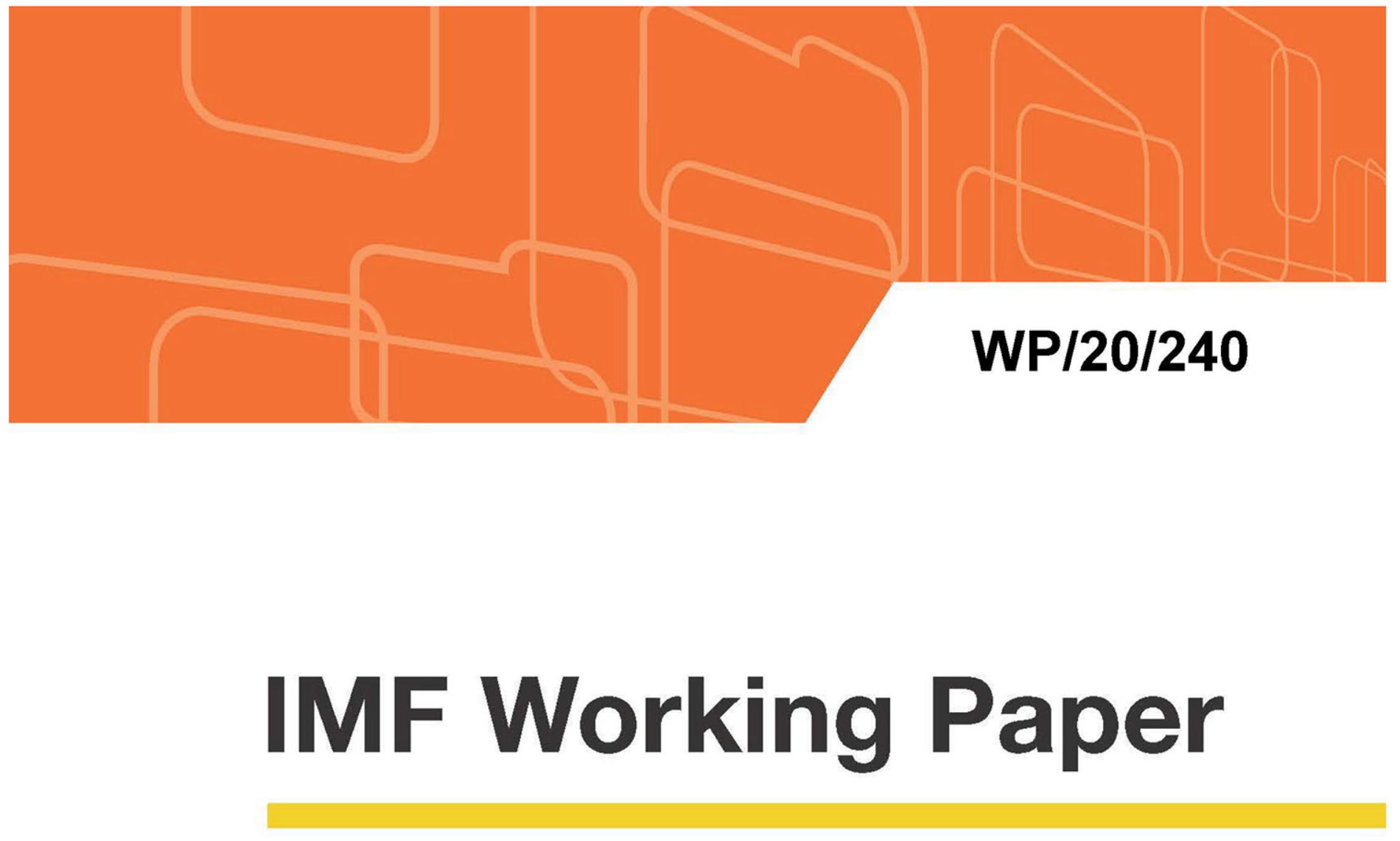

\title{
Inflation Expectations in the U.S.: Linking Markets, Households, and Businesses
}

by Peter D. Williams

IMF Working Papers describe research in progress by the author(s) and are published to elicit comments and to encourage debate. The views expressed in IMF Working Papers are those of the author(s) and do not necessarily represent the views of the IMF, its Executive Board, or IMF management. 


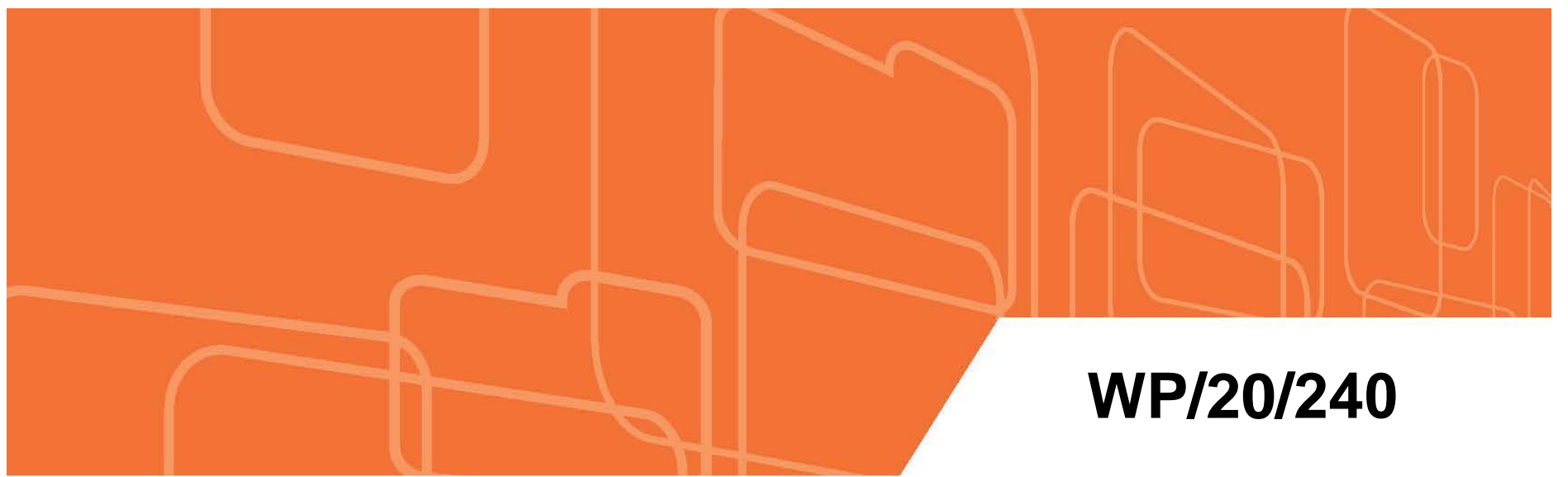

\section{IMF Working Paper}

\section{Inflation Expectations in the U.S.: Linking Markets, Households, and Businesses}

by Peter D. Williams

IMF Working Papers describe research in progress by the author(s) and are published to elicit comments and to encourage debate. The views expressed in IMF Working Papers are those of the author(s) and do not necessarily represent the views of the IMF, its Executive Board, or IMF management. 


\title{
IMF Working Paper
}

Western Hemisphere Department

Measuring Inflation Expectations in the U.S.

Prepared by Peter D. Williams ${ }^{1}$

Authorized for distribution by Nigel Chalk

November 2020

IMF Working Papers describe research in progress by the author(s) and are published to elicit comments and to encourage debate. The views expressed in IMF Working Papers are those of the author(s) and do not necessarily represent the views of the IMF, its Executive Board, or IMF management.

\begin{abstract}
Inflation has been below the Federal Reserve's target for much of the past 20 years, creating worries that inflation may be deanchoring from the FOMC's target. This paper uses a factor model that incorporates information from professional forecasters, household and business surveys, and the market for Treasury inflation protected securities (TIPS) to estimate long-run inflation expectations. These have fallen notably in the past few years (to roughly 1.9 percent for CPI inflation, well below the FOMC's target). It appears that, even before the covid recession, the private sector viewed the economy as likely to suffer from persistent headwinds to inflation.
\end{abstract}

JEL Classification Numbers: E31, E43, E44, G10, G17

Keywords: Inflation, inflation expectations, yield curve, factor modeling, no-arbitrage term structure model, TIPS, surveys

Author's E-Mail Address: pwilliams2@imf.org

\footnotetext{
${ }^{1}$ I would like to thank my colleagues on the U.S. desk for valuable comments on this paper and earlier research pieces which led to it. Note, the paper considers the effects of the covid-19 shock in the next-to-last section but earlier charts do not include it.
} 
II. AN EXTENSION OF TERM PREMIUM MODELING

A. Similar Models in the Literature

B. The Model

III. A MORE FLEXIBLE AND PESSIMISTIC VIEW

A. Model Results

B. Estimates of Inflation Expectations

C. The Estimated Inflation Risk Premium

D. The Liquidity Premium

IV. COVID-19

V. CONCLUSIONS

REFERENCES

\section{FIGURES}

1. CPI Inflation

2. Expectations of CPI Inflation

3. Inflation Expectations

4. Inflation Expected in the Long-run

5. Alternative estimates of long-run expectations

6. Decomposition of the 10-Year Breakeven Inflation

7. Liquidity Impacts on Breakeven Inflation Estimates

8. Inflation Expectations During Covid

\section{TABLES}

1. Factors' Speeds of Mean-Reversion 12

2. Share of Variance Explained

3. Measurement Errors

\section{APPENDIX}

Observation Equations 


\section{ThE CONQUEST OF INFLATION... AND ThEN What?}

Since the July 1996 meeting when the FOMC reached its internal agreement on a two percent inflation target for the personal consumption expenditure deflator (roughly 2.3 percent in CPI terms) core inflation has been at or above that target for only a fraction of the time (see Figure 1). ${ }^{2}$ Given that this period has included the Global Financial Crisis (GFC) some of this persistent weakness is to be expected due to the size of the financial and real shocks that occurred. The zero lower bound (ZLB) on interest rates (in many countries) constrained policy but was, at least partially, compensated for by reformulating forward guidance and putting in place quantitative easing programs. These were designed to boost growth through lower risk-free interest rates and a loosening in financial conditions. Despite a large initial stimulus, fiscal policy was, on net, only a modest support to growth over the post-Crisis period as well. As a result of these challenges, inflation in most advanced economies has remained stubbornly below its target since the GFC.

In the aftermath of the GFC there were concerns that inflation could accelerate rapidly (due to the large increase in the Fed's balance sheet) or the economy could fall into deflation (due to the large increase in unemployment and fall in capacity utilization). However, neither of these ended up happening - inflation remained slightly below target for most of the period.

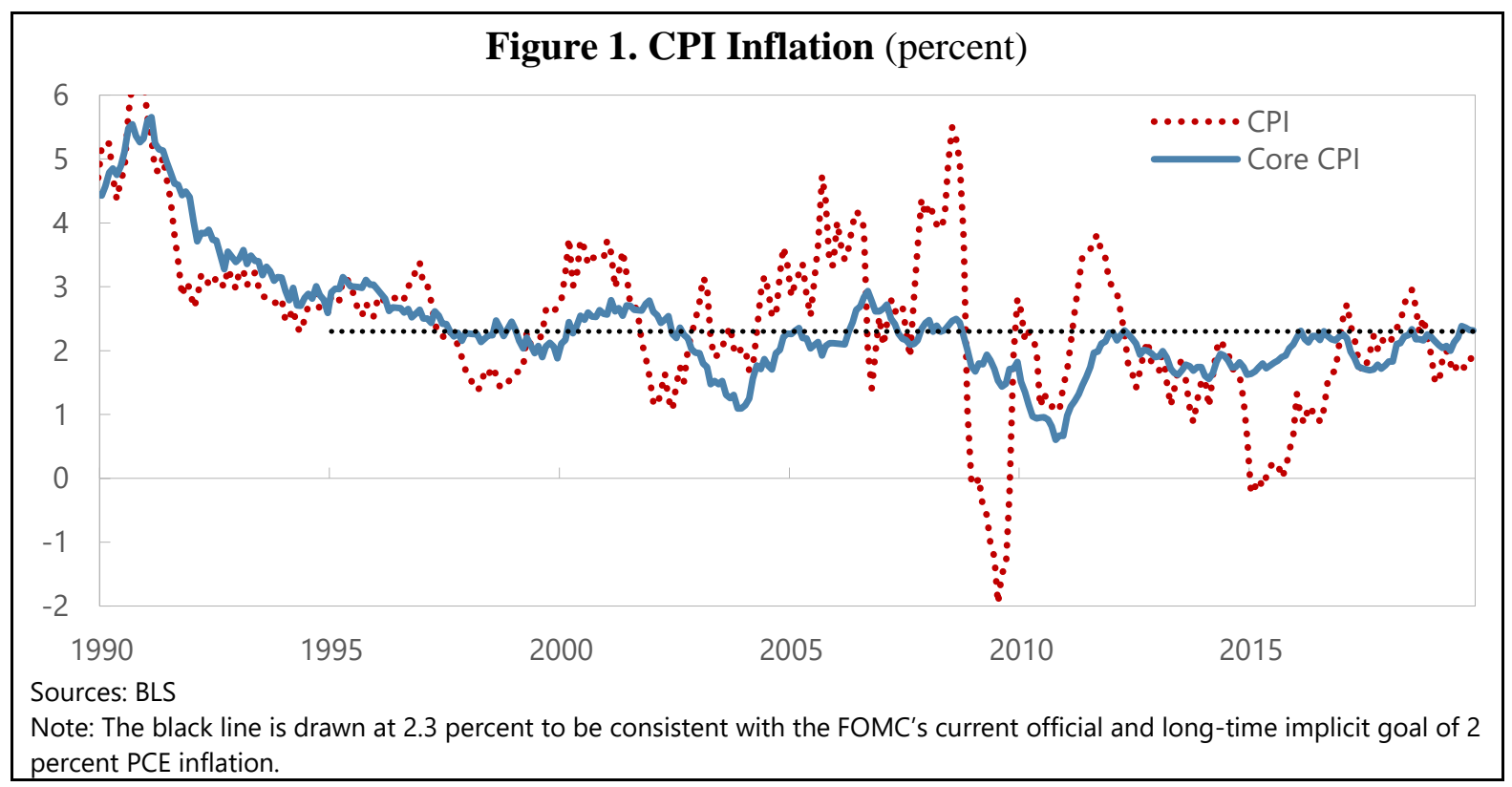

Since the GCF, especially after 2015, the FOMC has expressed concern that inflation expectations could become de-anchored to the downside from their long-run target (see Yellen 2015). Despite this, they began to raise interest rates in December 2015. Around then many (but not all) survey measures of inflation expectations began to drift downwards.

\footnotetext{
${ }^{2}$ This level was decided on as an optimal level of small but positive inflation, which reflected the FOMC's success in bringing inflation down over the previous 15 years. See pages 43-75 of the meeting's transcript for the full discussion. https://www.federalreserve.gov/monetarypolicy/files/FOMC19960703meeting.pdf
} 


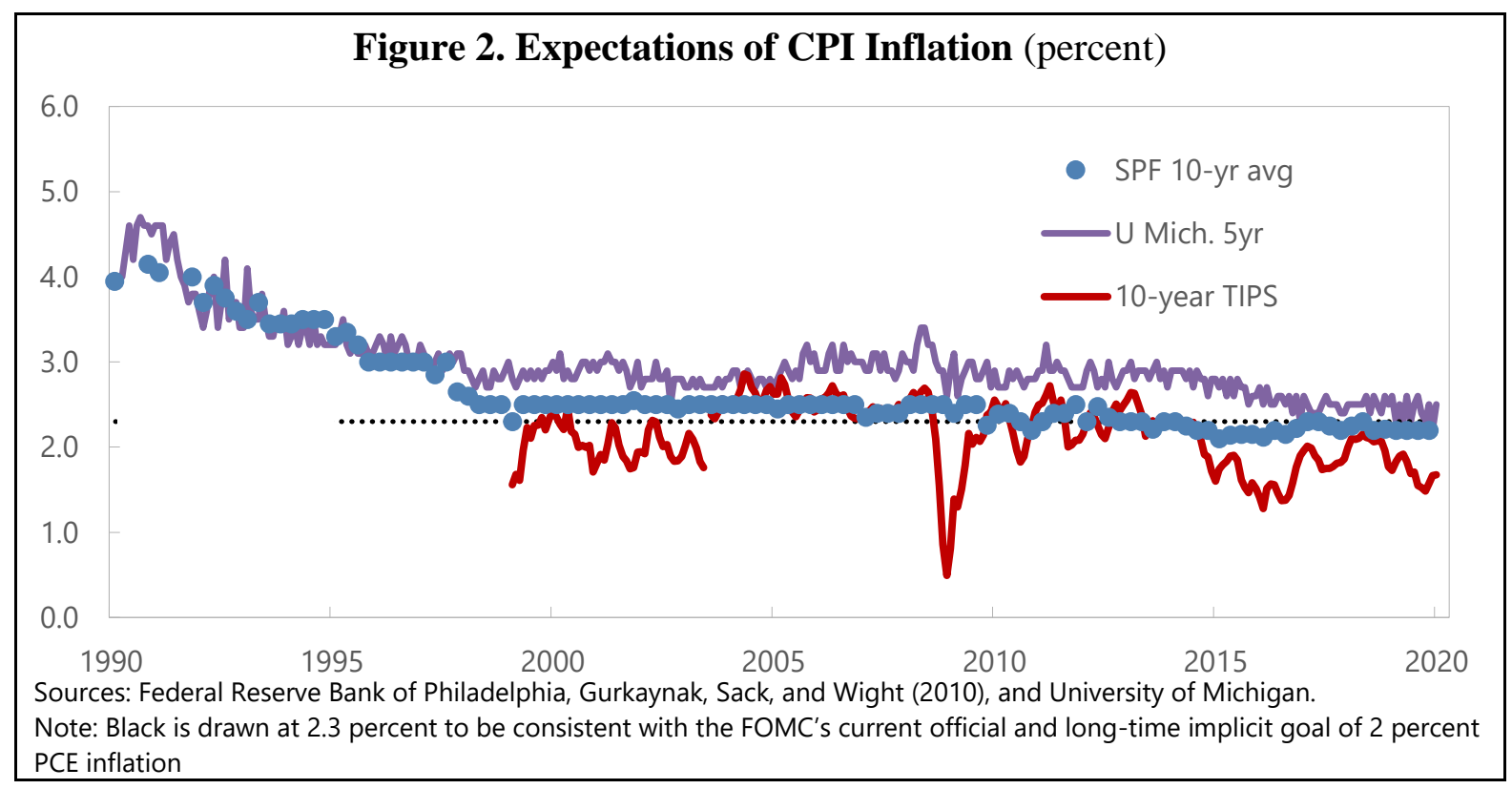

This paper explores the possibility that inflation expectations did shift in the post-GFC period and makes two methodological contributions:

1) By assuming the level of long-run expected inflation has a unit root, a more flexible model specification, the data has a stronger role in discriminating between transient and permanent movements in inflation expectations (since assuming a nonintegrated process for inflation and inflation expectations imposes long-run stability on the data).

2) The model uses a broader selection of surveys of households and businesses than most other approaches. The resulting measure of expectations should be indicative of cross-sector inflation expectations.

The results suggest that this comprehensive measure of long-run expectations of CPI inflation was largely stable from 2000 until 2014 at levels near 2.3 percent. However, over the past 5 years, expectations appear to have declined to just below 2 percent, a level well below that which would be consistent with the FOMC's long-run target (given that the Fed's target on inflation in the price index for personal consumption expenditures and CPI inflation has historically run modestly above PCE inflation). This decline of inflation expectations is significant (roughly three standard deviations below the previous range). It could reflect either fears about large expected output gaps as a normal state of the world (driving down average inflation with constant equilibrium inflation) or that agents now expect below target inflation and embed this into their own actions, which becomes a self-fulfilling forecast.

Section II introduces a term structure model based on TIPS and surveys of inflation expectations while sections III and IV use this framework to assess movements in inflation expectations through time. Section V concludes. 


\section{An Extension of Term Premium Modeling}

\section{A. Similar Models in the Literature}

The standard approach to extracting market expectations and risk premia from bond prices is to use a no arbitrage term structure model. These models are highly tractable and well documented in the literature. ${ }^{3}$ In these models, observed yields on bonds ( $y_{t}^{\tau}$, with maturity $\tau)$ can be decomposed into forward looking expectations of the short-term rate $\left(E_{t}^{\tau}[f f]\right)$ and the term premium ( $t p_{t}^{\tau}$, the risk premium driven the state of the economy and the uncertainty about the path of short-term rates).

$$
\text { 4) } y_{t}^{\tau}=E_{t}^{\tau}[f f]+t p_{t}^{\tau}
$$

A similar term premium-like decomposition is possible for the breakeven inflation series from the TIPS market. Breakeven inflation (BEI) is defined as the difference between the yield on nominal $\left(y_{t}^{\tau}\right)$ Treasury and real $\left(r_{t}^{\tau}\right)$ TIPS yields. We can decompose both of these into expected rate and risk premium components; it is also important to allow for differential liquidity $\left(l i q_{t}^{\tau}\right)$ between these markets as they have different market participants and there are not strong no arbitrage relationships between them. ${ }^{4}$ The inflation risk premium $\left(\operatorname{irp}_{t}^{\tau}\right)$ is the difference between the risk premia on nominal bonds and TIPS, and represents the excess yield on nominal bonds to compensate for their inflation risk.

$$
\text { 5) } \begin{gathered}
B E I_{t}^{\tau}=y_{t}^{\tau}-r_{t}^{\tau}=\left(E_{t}^{\tau}[f f]+t p_{t}^{y, \tau}\right)-\left(E_{t}^{\tau}[\text { real }]+t p_{t}^{r, \tau}+l i q_{t}^{r, \tau}\right) \\
\text { 6) } B E I_{t}^{\tau}=E_{t}^{\tau}[\pi]+i r p_{t}^{\tau}-l i q_{t}^{\tau}
\end{gathered}
$$

In these no arbitrage term structure models, the expectations of short-term rates and term premia are driven by a set of factors while the relationship between bond yields are governed by standard no arbitrage pricing. ${ }^{5}$ Models of this type usually share the same basic set of features:

1) Dimension reduction: they reduce the yield curve and any other data (most commonly surveys) to a relatively small number of factors. Given the large number of parameters in these models, dimension reduction is important to keep them tractable and reduce out-of-sample instability.

\footnotetext{
${ }^{3}$ See Adrian, Crump, and Moench, 2013; Dai and Singleton, 2001; Joslin, Singleton, and Zhu, 2011, and Kim and Wright, 2005 for different modeling approaches inside this broader paradigm. Kim and Orphanides, 2007, 2012; Kim, 2009; and Cochrane, 2007 offer broad overviews of the literature and discuss some of the problems that can afflict these models.

${ }^{4}$ The liquidity effect biases up real TIPS yields and down breakeven rates of inflation.

5 The factors can be completely latent and unobserved or linked to observed data. If the factors are fully unobserved some normalizations of the factor dynamics will be required to ensure identification and stability. Models with observed factors have often used the yield curve's principal components. Macroeconomic data and surveys have also been used to either constrain the factor dynamics or to identify the factors.
} 
2) The risk premia and expected interest rates and/or inflation are affine (linear) functions of the estimated factors.

3) The factors follow vector auto regressive (VAR) dynamics. This implies the yield curve will be forecast to revert to its average shape and level.

4) They have Gaussian shocks. This makes the models more tractable if less realistic.

These models face several statistical issues given the short-term persistence and long-run instability of inflation and the level of interest rates. Given the relative infrequency of business cycles, the small sample problem frequently leads to over-estimation of how fast the factors will mean revert. In addition, model's which do not allow for time varying means for the level of interest rates or inflation will tend suffer from end-of-sample stability issues and may, particularly when observed values are far from the historical mean, over- or under-state long-run expected values. Lastly, the models are often very richly parametrized, and this can lead model instability in real-time settings.

The inclusion of survey data can help to address these problems. Guimarães (2014) and Kim and Orphanides (2012) both show that the adding survey data can lead to more stable models (effectively by increasing the amount of cross sectional information and anchoring the dynamics of the underlying data series). ${ }^{6}$ Even fairly short samples for surveys can lead to improvements in the model stability. ${ }^{7}$ Indeed, the relative instability of models which do not include surveys is well documented in Guimarães (2014), Li and others (2017), and Klein (2016). If there are time varying trends, models drawing on survey data may capture these changes more quickly. They can also help parsimoniously capture difficult to model and estimate features such as the zero lower bound without requiring more complicated modeling approaches. Similar improvements hold for inflation as well as nominal interest rates. In a comparison of forecasting performance Faust and Wright (2013) show that inflation surveys outperform model-based forecasts for inflation up to a 2-year horizon. In part, this is because surveys can incorporate a variety of distinct modeling approaches, expert judgement about short-term shocks, and more easily strike a balance between structural change and stability.

Another approach to increase model accuracy and structural stability is to allow for timevarying trends in the underlying economic series. In Duffee (2013) and Bauer (2017), models of nominal interest rates which have a time varying level are found to be more accurate than models which assume mean-reversion in the level of rates. Usually this requires linking the time-varying trends to something (e.g. surveys or policy goals) for tractability and consistency.

\footnotetext{
${ }^{6}$ That is, the mean-reversion matrix, $k$, of the factor dynamics is better specified in the presence of surveys than just market data. Monte Carlo studies in these papers show that the inclusion of surveys reduces the bias and uncertainty of the estimated parameters substantially.

${ }^{7}$ Guimarães (2014) summarizes the advantages of surveys in this way: "Even if not the best on forecasting horse races, models that roughly match survey forecasts have the benefit that they are automatically sensible in different time periods and environments, not subject to data snooping and consistent with information sets in real time."
} 
The simplest way to integrate the information from inflation-linked bonds, analyst forecasts and surveys results is to use a state space model. These models are one of the most common ways of extracting information from fixed income markets. Kim and Wright (2005) and D'amico, Kim, and Wei (2018, DKW from here on) are the two benchmark models of this type. Both these models draw on surveys of economists and data from bond markets.

\section{B. The Model}

The model uses the following data: 12-month CPI inflation, TIPS breakeven inflation rates (with 2, 5, 7, 10, 15, and 20 year maturities from the Gurkaynak, Sack, and Wight, 2010 database), surveys of economists and market participants at short and longer-term horizons, and household and business surveys (see Appendix I for detailed data source information and the estimated observation equations). To anchor the factor model, we include de-meaned values of oil price changes (to account for supply side shocks to headline inflation) and the CBO's unemployment gap (as a measure of the cyclical position of the economy). ${ }^{8}$ The use of both surveys and macro data imposes some structure on the model and makes the factors easier to interpret. This particularly true given that measures of break-even inflation, especially at short horizons, are sensitive to movements in oil prices and shocks to funding conditions or bond market liquidity (Figure 3).

Model selection aims to balance realism, parsimony, and quasi-real-time stability. In addition, we believed that the inflation risk premia should generally be positive over the sample and the premium for liquidity risk should be negative (since TIPS are less liquid than comparable maturity Treasury bonds).

This paper's four factor model is specified as follows:

- Factor 1: long-run expected level of inflation. This estimate incorporates market and survey participants' long-run expectations of the output gap and supply shocks. The long-run expected level of inflation is constrained to be a unit root (this has support in the term premium modeling literature: Bauer and Rudebusch, 2017; Cochrane, 2007; Duffee, 2013; and Kim, 2009 all find that the level of nominal interest rates is best described as a unit root). By not imposing mean-reversion this will lessen the bias toward assuming the inflation target is credible and that inflation expectations are well-anchored (instead, if expectations are actually stable the unit root assumption will imply no drift with most of the variation in expected inflation arising from temporary factors and shifts in risk-premia). ${ }^{9}$

- $\quad$ Factor 2: economic slack. For simplicity and transparency, the model uses the (demeaned) $\mathrm{CBO}$ measure of the unemployment gap.

\footnotetext{
${ }^{8}$ Because the output gap is demeaned its absolute level is relatively unimportant and only its fluctuations around its mean matter. Due to this, the model is fairly robust to choices of the output gap so long as the output gap in question is consistent with an estimate of slack from an anchored expectations Phillips Curve.

${ }^{9}$ This logic assumes the sample average of inflation is close to its target.
} 
- $\quad$ Factor 3: temporary supply shocks. This is relative oil price inflation. Oil prices have been shown to have "undue" impacts on inflation-linked markets (Lumsdaine, 2009).

- $\quad$ Factor 4: the liquidity differential between TIPS and nominal Treasury securities. This illiquidity bias has been well documented during the first few years TIPS were trading and has re-emerged in recent years as a driver of breakeven inflation rates. ${ }^{10}$ Unlike the other factors, this one is entirely endogenous to the model.

The twelve-month inflation rate is assumed to be an affine function of the first three state variables. The liquidity factor does not directly effect inflation expectations but does affect TIPS pricing. The unity coefficients normalize the magnitudes of the factors.

$$
\text { 7) } \pi_{t}=\delta \boldsymbol{X}_{t} \text {, where } \delta=[1,1,1,0] \text {. }
$$

The factors evolve according to the following transition equation:

$$
\text { 8) } \begin{array}{r}
\boldsymbol{X}_{t}=\mu+\kappa \boldsymbol{X}_{t-1}+\Sigma e_{t} \\
\kappa=\left(\begin{array}{cccc}
1 & 0 & 0 & 0 \\
0 & k_{2,2} & 0 & 0 \\
0 & 0 & k_{3,3} & 0 \\
0 & 0 & 0 & k_{4,4}
\end{array}\right)
\end{array}
$$

The diagonal terms in the $k$ matrix are the estimated speeds of mean reversion. The meanreverting series are assumed to have means of zero $(\mu=0)$, and $\boldsymbol{\Sigma}$, the estimated covariance matrix of the shocks, is diagonal. Alternate identifiable speciation's of both $\kappa$ and $\Sigma$ were tested but did not increase model performance noticeably and often to less stable model outputs when applied to different samples. ${ }^{11}$

The factors are have observation equations of the following form:

$$
\text { 9) } Y_{t}^{i}=c+\beta \boldsymbol{X}_{t}+\eta^{i}
$$

For the surveys, $\beta$ is determined by the transition equation's dynamics; this ensures internally consistent expectations and helps control for the small sample problems. The consumer and business surveys have a constant term that allows for possible persistent biases in their inflation forecasts. For the TIPS yields, the values of $c$ and $\beta$ are implied by the no arbitrage pricing model dicussed below.

In theory, 10-year inflation expectations surveys should both incorporate cyclical dynamics and the equilibrium rate of inflation. However, as Thomas (1999) shows, the longer-run

\footnotetext{
${ }^{10}$ See DKW; Dudley, Roush, and Steinberg Ezer, 2009; Sack, 2007; and Sack and Elsasser, 2004.

${ }^{11}$ For examples of the parsimony principle see Christensen and others, 2011; Diebold and others, 2005. In both these papers simpler models, those with fewer parameters and less richly specified cross-factor dynamics, are shown to be more stable and often better out-of-sample forecasters than more richly specified ones with only small decreases in in-sample performance.
} 
survey of professional forecasters seems to be biased upwards and is insufficiently cyclical given the length of U.S. business cycles (they also seem to implicitly assume that the output gap is mean zero which is not consistent with U.S. data; see Aiyar and Voigts, 2019 and Congressional Budget Office, 2015 for theoretical discussions as to why this may be the case). Unlike in the economist surveys, this issue much reduced for the market surveys from the New York Fed. As a result, the model weights these (admittedly shorter sample) surveys more heavily as they are more consistent with the other data and surveys.

Finally, the market price of inflation risk is an affine functions of the state variables. ${ }^{12}$

$$
\text { 10) } \Gamma_{t}=\lambda_{0}+\lambda_{1} \boldsymbol{X}_{t}
$$

Empirical estimates suggested placing some restrictions on the prices of risk. Without these restrictions the liquidity factor, expected level of inflation, and inflation risk premim are less stable in quasi-real-time tests. In $\lambda_{0}$ constant prices of risk are estimated for the first three factors while the fourth term, corresponding to the liquidity factor is set to zero. $\lambda_{1}$ is set to be diagonal where each factor price of risk is determined by its own level, and we allow the liquidity factor to impact the pricing of each of the other factors as well. ${ }^{13}$ This balances parsimony and stability with accurately describing the data. It also leads to a higher loglikelihood than an unrestricted version of the model. ${ }^{14}$

Under standard no arbitrage assumptions, zero coupon bond yields are also an affine function of the state variables and the bond pricing recursions below determine the zero coupon yield.

$$
\begin{gathered}
\text { 11) } A(\tau)=A(\tau-1)+B(\tau-1)^{\prime}\left(\mu-\Sigma \lambda_{0}\right)+\frac{1}{2} B(\tau-1)^{\prime} \Sigma^{\prime} \Sigma B(\tau-1) \\
\text { 12) } B(\tau)=B(\tau-1)-\check{\delta}-\left(k-\Sigma \lambda_{1}\right)^{\prime} B(\tau-1) \\
\text { 13) } y_{t}^{\tau}=-\frac{1}{\tau} A(\tau)-\frac{1}{\tau} B(\tau)^{\prime} \boldsymbol{X}_{t}
\end{gathered}
$$

The model is estimated using the Kalman Filter on end-of-month data. Survey results are treated as missing data except in the month in which the surveys are reported.

\footnotetext{
${ }^{12}$ In this (or similar) affine specification you can easily map to the three versions of the expectations hypothesis: that there is no risk premia in bonds (forward rates are unbiased predictors of future short-term rates and $\lambda_{0}=\lambda_{1}=0$ ); there is a constant risk premia (the term/inflation risk premia exists and is constant at each maturity over time or $\lambda_{0} \neq 0$ and $\lambda_{1}=0$ ); or time varying risk premia (forward rates are largely a function of risk premia, not rate expectations and at least one element of $\lambda_{1} \neq 0$ ).

${ }^{13}$ A similar approach is taken in Ilhrig and others, 2018, when measurising the impact of large scale asset purchases on the term premium.

14 The likelihood surface often has many local maxima and the fully unrestricted version of the model may be too difficult to estimate reliably using classic maximum likelihood methods when two of the factors are latent.
} 


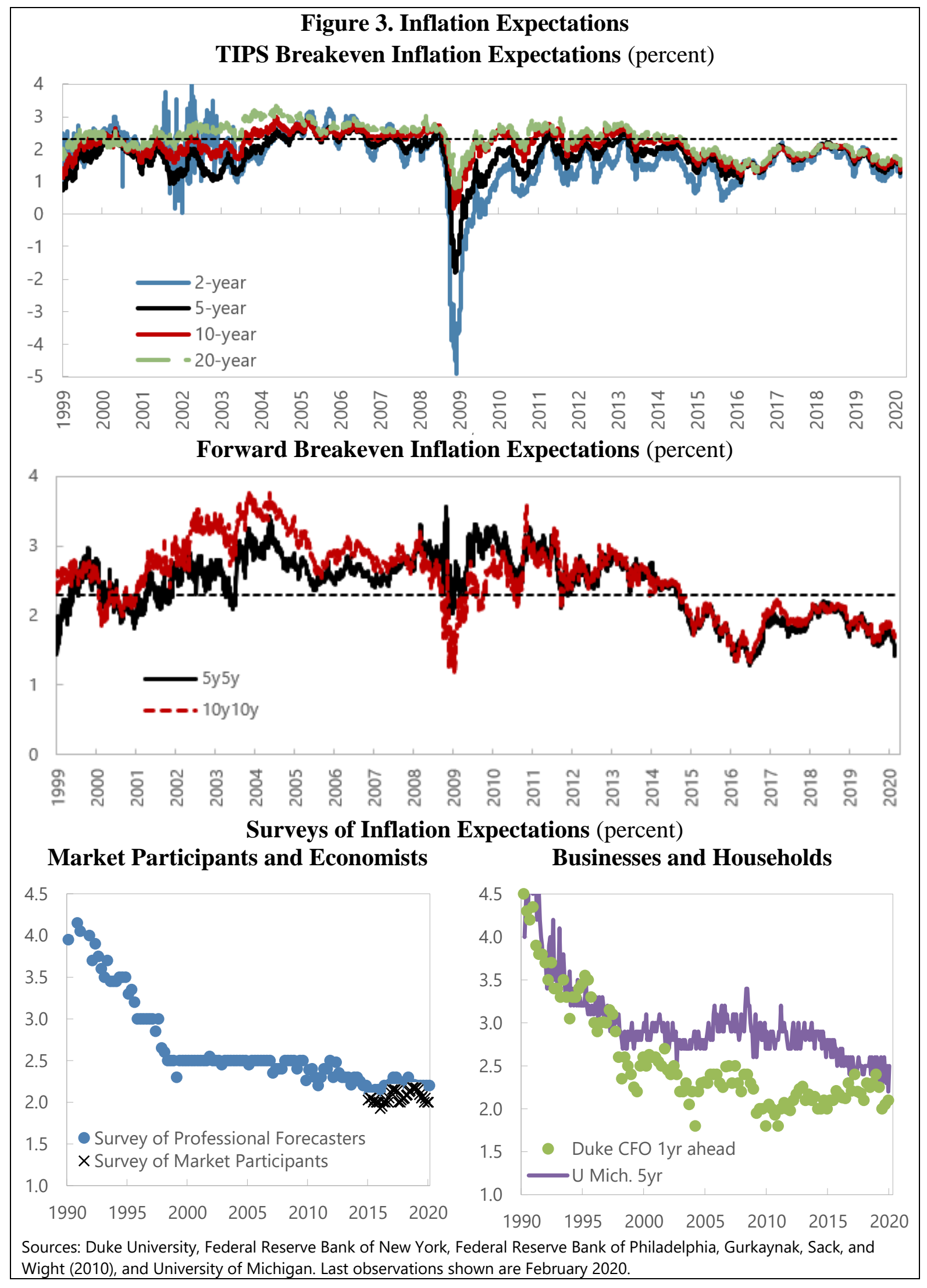

CInternational Monetary Fund. Not for Redistribution 


\section{A More Flexible And Pessimistic VieW}

\section{A. Model Results}

The parameter results from the model are in line with the literature. The output gap declines relatively slowly while the impact of oil prices shocks almost fully fades out within a year. Interpreting the liquidity shock is more difficult as it not relevant to inflation expectations and only effects TIPS pricing; in this sense, its persistence reflects how evenly distributed liquidity effects are across the term structure (a value greater than one would've implied that the effects were larger for longer-maturity securities). The ordering of the volatilities of the different states are also in line with what we would expect; oil price and liquidity effects are more volatile than the trend rate of inflation and the unemployment gap (which has historically been fairly

Table 1. Factors' Speeds of Mean-Reversion stable).

A simple variance decomposition shows that the inflation breakevens' variation is largely driven by movements in the inflation risk premium and liquidity conditions. This is keeping with the other papers on inflation breakeven and nominal interest rates (see Crump and others 2016, DKW, and Sack, 2007). As one moves farther out the maturity spectrum, the impact of liquidity shocks fades. Expected inflation and the inflation risk premium are more important at the long-end; for longer-maturity securities the inflation risk premium is the main driver of inflation risk.

The model's fits for the breakeven inflation series are quite accurate. Given the outsized impacts of oil prices, and the fact that we do not take into account the deflation floor built into TIPS, the relatively poor fit for two-year breakeven is not surprising (The deflation floor is the implicit option that arises in TIPS because their principal value can never go below 100, so large bouts of deflation are

\begin{tabular}{|c|c|c|c|}
\hline & $5 \mathrm{Y} \mathrm{BEI}$ & $10 \mathrm{Y} \mathrm{BEI}$ & $20 \mathrm{Y} \mathrm{BEI}$ \\
\hline Expected Inflation & 0.13 & 0.26 & 0.32 \\
\hline Inflation Risk Premium & 0.01 & 0.23 & 0.52 \\
\hline Liquidity Premium & 0.86 & 0.51 & 0.16 \\
\hline
\end{tabular}

\begin{tabular}{|ccc|}
\hline \multicolumn{3}{|c|}{ Table 3. Measurement Errors } \\
(percentage points, \\
std. dev)
\end{tabular}


truncated out of the distribution). ${ }^{15}$ In general no-arbitrage models of this type tend to fit the curve most accurately in the middle 5-10 year segment where pricing idiosyncrasies and time-varying convexity effects have less influence.

The pattern of fitting the quarterly forecasts is unsurprising, as the surveys uses quarterly inflation while our base series is the 12-month change in CPI. As a result, the model fits best at three and four quarter horizons where short-term shocks have largely been filtered out. The two long-horizon surveys of economists have very similar measurement errors; the Survey of Market Participants and Primary Dealers have substantially smaller errors.

\section{B. Estimates of Inflation Expectations}

The model estimates of long-run inflation expectations show that they declined substantially throughout the early 1990s as the Fed's disinflationary project, begun in the late 1970s, continued. From 1998-2014 inflation expectations were largely stable at levels very close to FOMC's implied target of 2.3 percent for CPI inflation (Figure 4).

In recent years expectations have fallen below the levels that are consistent with the FOMC's target. Long-run inflation expectations began moving downwards in 2014 at a time when the FOMC was signaling that interest rates would soon be on an upward path, when oil prices were falling, and the US\$ was appreciating. Markets, businesses, and households during this period appeared skeptical of the ability to achieve the 2 percent inflation target given low neutral interest rates, the effective lower bound and secular disinflationary headwinds. This decline in inflation expectations came during a period when core inflation has been consistently below the 2 percent target for a decade (see Powell, 2018 and Clarida, 2019). It is worth recognizing that the extent and persistence of the cyclical and structural headwinds that have weighed on inflation since the crisis took some time to be recognized.

The fiscal stimulus put in place in 2017 provided a small boost to the outlook for growth, reduced slack, and supported a modest drift upward in inflation expectations as estimated by the model. By mid-2018 as the FOMC continued to raise rates, financial conditions tightened, risk aversion rose, and expected inflation fell (see Bernanke and others, 2020; Chung and others, 2019; and Gagnon and Collins, 2019). Market commentary at the time suggested that this post-stimulus decline in interest rates and BEIs was largely due to differing perceptions between the Fed and market participants about how far interest rate normalization could proceed.

\footnotetext{
${ }^{15}$ In the beginning of the sample the shorter-maturity part of the BEI curve was sparsely populated (see Figure 1 in Gurkaynak, Sack, and Wight (2010)) as a result some noise was introduced and the measurement error on the 2-year BEI is somewhat higher than current conditions would reflect. Given the long-horizon measures of expectations we're focused on this has minimal effect on the final estimates.
} 


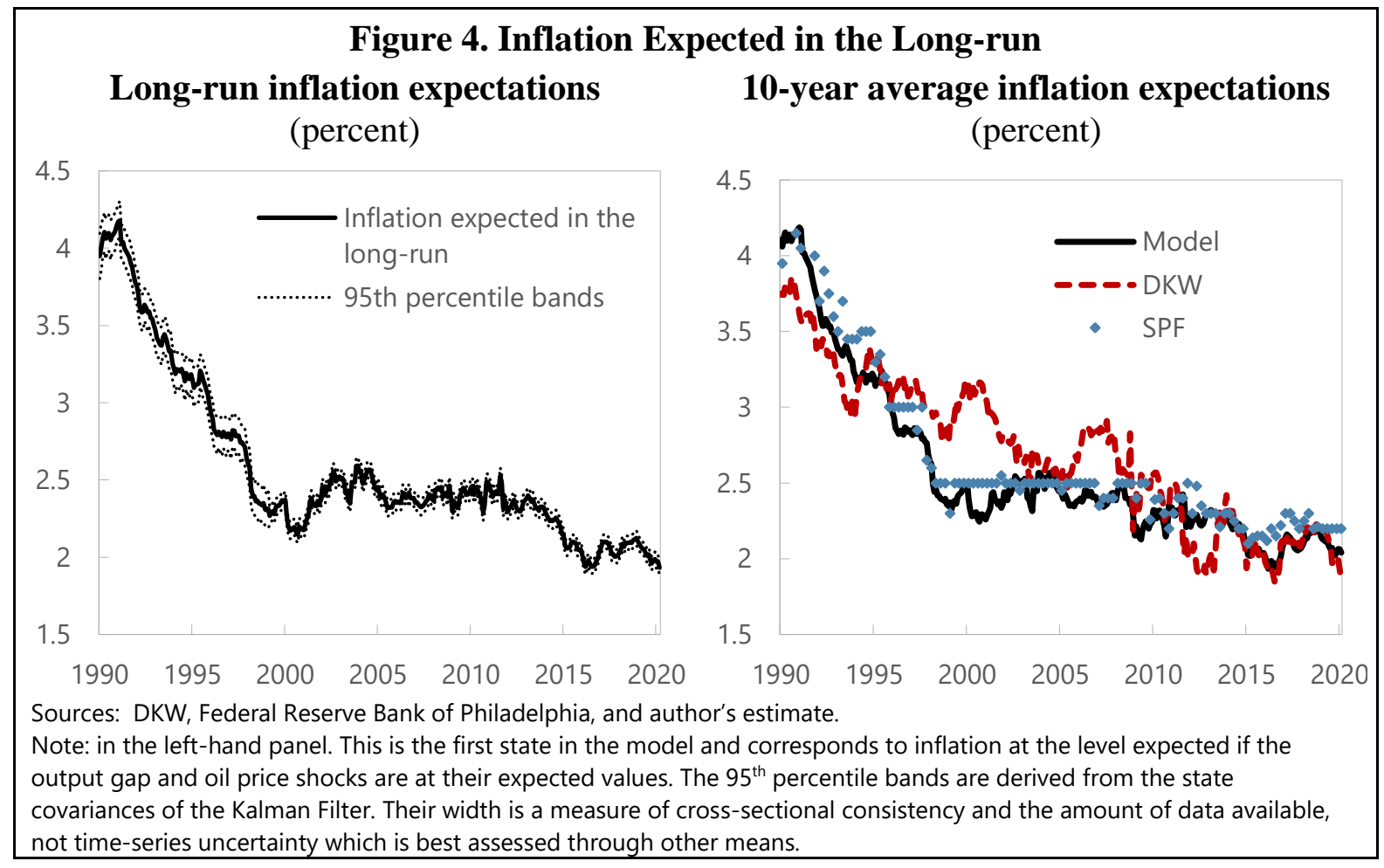

The filtered results from the model are robust to changing the cross-sectional sample (i.e. applying the estimated Kalman filter to only TIPS data or including different survey measures). This stability gives some confidence that model can generate long-run expectations estimates which are reasonable cross sectional approximations and don't depend heavily on any one data type or series (Figure 5). This paper's estimated results and parameters reflect a wide variety of surveys and data. ${ }^{16}$

The estimate based on households and business surveys is higher and more volatile than the baseline one. It looks similar to a smoothed version of the headline CPI series and responds more strongly to supply shocks (consistent with evidence that households have a larger response to news during bad states of the world, see Kamdar 2020).

It's worth noting that the goal of this paper's modeling approach isn't to optimally model expectations but to extract them from a number of data sources in any internally consistent way. This may lead to estimates parameter estimates or factor loadings which are suboptimal for any given series, but which describe the overall economy's views well and are consistent across time and the different series.

\footnotetext{
${ }^{16}$ If the Kalman filter is estimated with different blocks of the data set excluded the same general stability is true as long as the macro data are included.
} 

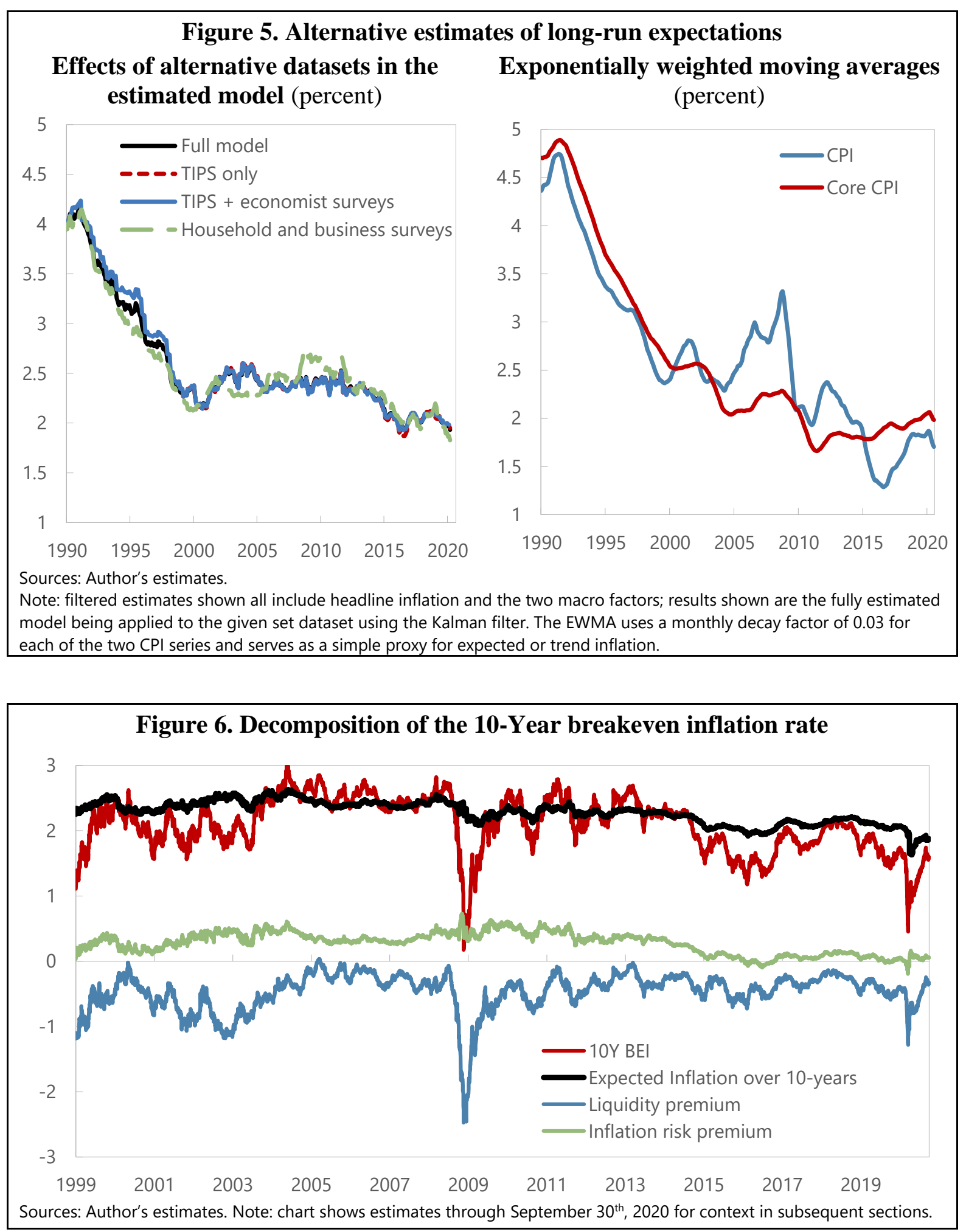


\section{The Estimated Inflation Risk Premium}

Along with declining estimates of expected inflation and falling realized volatility of inflation the estimated inflation risk premium has declined over time. Since 2016, this risk premium has been close to zero (in line with results in other advanced economies, see Böninghausen and others, 2018; Figure 6). Breakeven inflation exhibits an excess sensitivity to oil price shocks, in line with the literature ${ }^{17}$ Lower slack tends to increase the inflation risk premia (presumably since realized inflation should be expected to be higher as capacity constraints become more binding). In the end, most of the risk premium is driven by the level of inflation - this is similar to the findings that nominal interest rates' term premia are largely driven by risks to the overall level of interest rates and not other factors affecting the yield curve.

\section{The Liquidity Premium}

The overall dynamics of the liquidity premium suggest that the initial illiquidity effects in the TIPS market had largely dissipated by 2005 (similar to results in Sack, 2007 and other work), but were exacerbated during the global financial crisis as investor risk aversion rose and funding conditions for all leveraged investment vehicles deteriorated. These liquidity effects have provided a modest but generally stable drag on BEIs during the post-GFC period. The time series of the liquidity impact in Figure 7 is similar to that estimated by DKW (shown) and the returns-regression based no-arbitrage model of Abrahams and others (2016). Liquidity effects are more impactful for short-term instruments than for longer-term bonds. While not particularly intuitive or obvious, this result is robust across methodologies.

The model assumes that expectations and inflation risk-premia are directly linked to the three macro factors. However, the liquidity effect, which is the non-macro component of the BEI curve, is time varying and consistently priced (obeys no-arbitrage rules). ${ }^{18}$ Alternatively, the liquidity premia could at least partially represent a non-linear risk premium associated with extreme changes in the macroeconomy and oil prices.

The liquidity premia, and the under-prediction of inflation by BEIs it results in, is an additional source of yield for all investors in the TIPS market (Dudley and others, 2008; GAO, 2009; and Holstein and others, 2010). It has also, particularly during times of stress, created lucrative opportunities for arbitrageurs and tactical traders. ${ }^{19}$

\footnotetext{
${ }^{17}$ Vlieghe (2018) summarizes the inflation risk premium in this way: "Investors need to be compensated for the risk that future inflation turns out differently from today's expected inflation. Again, the covariance point is key: investors will demand an inflation risk premium if inflation surprises on the upside precisely at the time when consumption growth is weak. And the inflation risk premium will be higher if inflation is persistent, i.e. if inflation drifts away from its previously expected level for a long time. If, instead, inflation surprises on the downside when consumption growth is weak, the inflation risk premium should be negative."

${ }^{18}$ An alternative phrasing is that the liquidity effect is a serially correlated measurement errors from the macro factors that effects the entire BEI curve.

${ }^{19}$ The liquidity issues in TIPS provided "the largest arbitrage ever" for some traders during the GFC, see Kaminsky (2010) and Holstein and others (2010).
} 


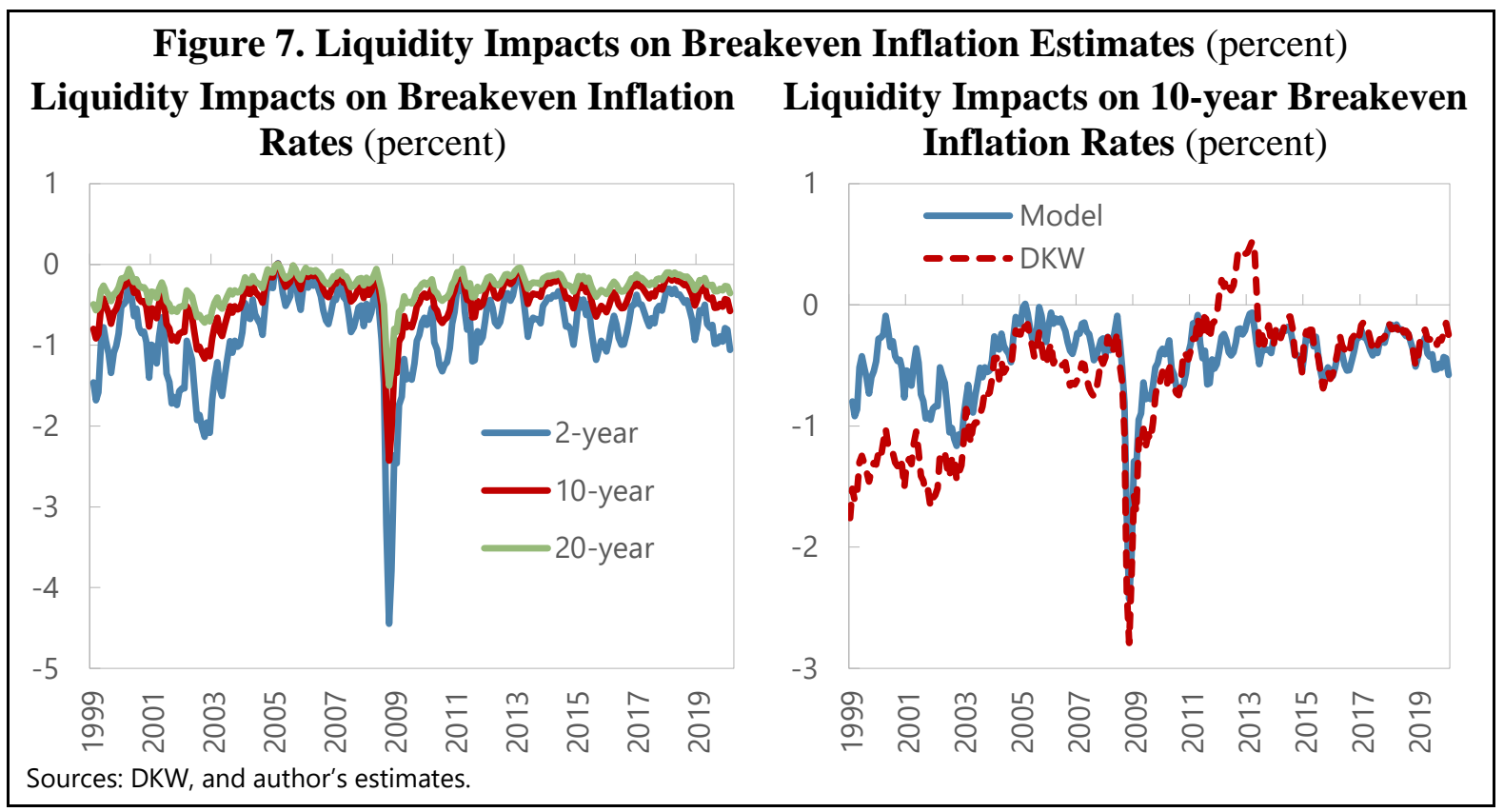

\section{CoviD-19}

Given the temporary breakdown in Treasury market functioning and the unprecedented size of the macroeconomic shocks, macrofinancial modeling of the covid-19 shock is quite a challenge. There has been vigorous debate about whether the effects of the pandemic will or will not be inflationary depending on the relative magnitudes and degree of persistence of the supply and demand effects of the pandemic.

Inflation expectations from the model currently suggest that the covid shock will be, on net, deflationary with 10-year inflation expectations having fallen by 20 basis points relative to pre-pandemic levels (Figure 8). ${ }^{20}$ Expectations, across measures, troughed during the peak of the crisis in April. Since then, the increasing likelihood of effective treatments and vaccines have combined with better than expected macroeconomic and robust policy response to retrace some of the initial declines.

Consumer surveys have regarded the shock as inflationary (likely because the most frequently-observed prices for consumer staples have risen). The estimated liquidity effects during the covid shock were roughly half as large, but much shorter-lived, than those during the GFC (as risk aversion initially spiked but then quickly retraced that increase as policies were put in place to support bond market liquidity and the economy; see Figures 6 and 8). Longer maturity measures of inflation expectations have been more stable while shortermaturities experienced heightened volatility.

\footnotetext{
${ }^{20}$ We keep the macro data in the model even though the unique nature and size of the shocks means that this could potentially affect the results. While some of the factors move substantially as the simple dynamics of the transition equation are not able to entirely grapple with a shock like covid, any oddities seem to offset one another as the expected path of inflation looks very reasonable. See Holston and others (2020) for a related discussion.
} 


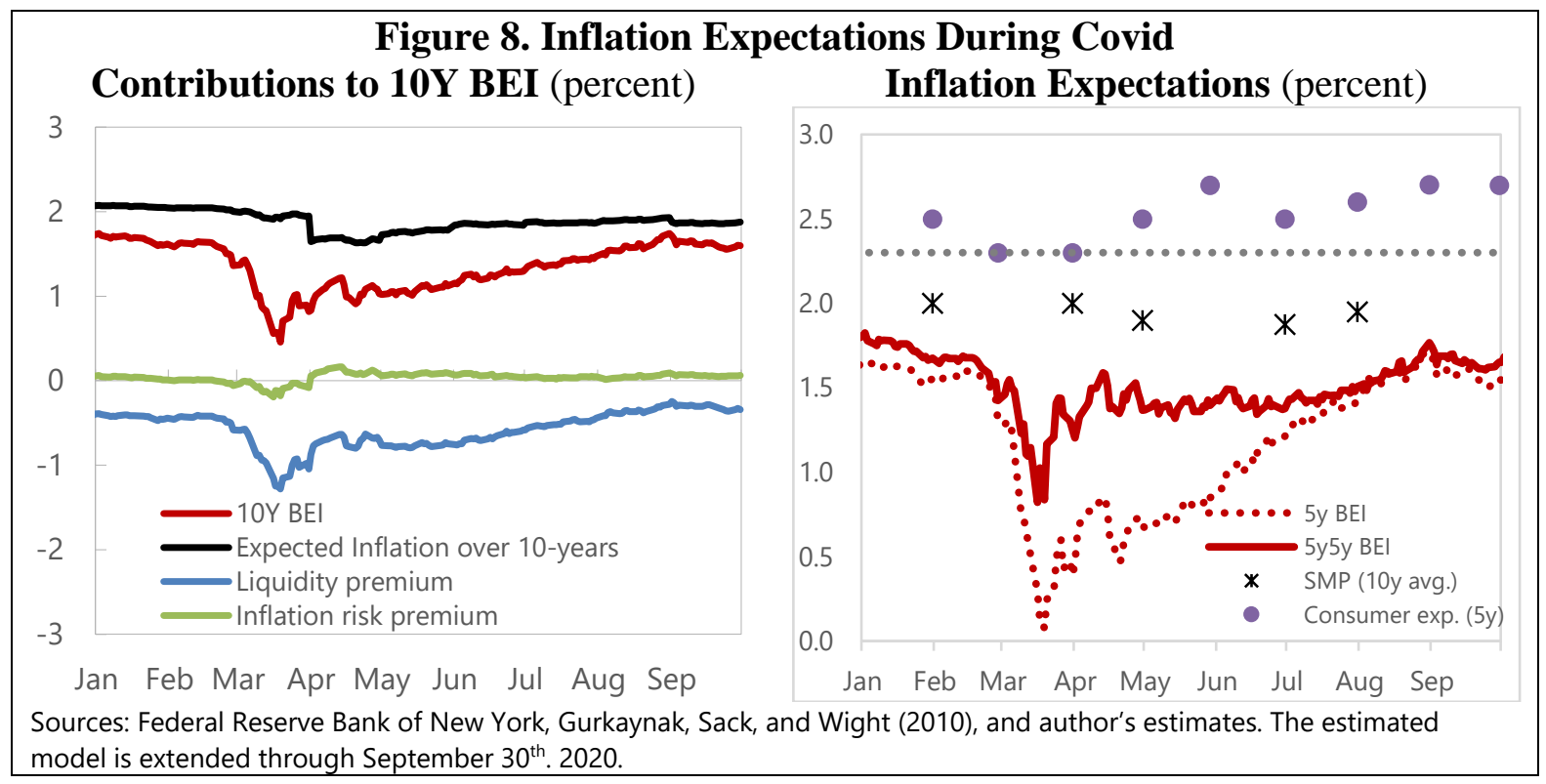

\section{Conclusions}

Model estimates that incorporate information from financial market pricing, professional forecasters, and household and business surveys suggest that longer-run inflation expectations have drifted down over the past six years. The decline in the neutral interest rate in the U.S., persistent levels of slack ${ }^{21}$, and various headwinds (such as from shale oil, movements in the U.S. dollar, and imported disinflation due to globalization) suggest that monetary policy in the U.S. will find it more challenging to get inflation to reach (or rise above) the Fed's 2 percent target. The recent softening of inflation expectations is likely to add to those challenges.

Macroeconomic models that routinely assume well anchored inflation expectations may well incorporate an assumption that is at odds with the data. In so doing, these models will likely systematically over-estimate the path for realized inflation. Given a very flat Philips Curve, unemployment would need to be reduced to very low levels to offset the impact of the observed decline in inflation expectations. This is particularly true if this deanchoring of expectations exerts its own self-fulfilling effects on inflation beyond just reflecting expectations of slack.

It will be interesting to see if the FOMCs new approach to its long-term goals and monetary policy strategy (regarding its maximum employment mandate as asymmetric and adopting flexible average inflation targeting) will be able to raise inflation expectations and lessen the

\footnotetext{
${ }^{21}$ The output gap has average between -1.5 and -3 percent over the last two full business cycles (depending on the model used). See Fleischman and Roberts (2011) and Williams, Abdih, and Kopp (2020) for discussions of output gap estimation approaches and how they relate to they relate to different inflation processes.
} 
risks of being stuck in a low inflation equilibrium with policy rates at the effective lower bound. ${ }^{22}$

Ultimately, the success of these types strategies will depend on the ability of policy makers to run the economy hot enough to sustainably push inflation up to, and for a time past, 2 percent. This will eventually require periods medium-run expectations above the prior 2 percent target. ${ }^{23}$ This is a somewhat counter-intuitive thought for many who came of age during the active disinflation of the Volcker and early Greenspan eras; a fear of inflation deanchoring to the upside has been replaced by a reality of inflation expectations below target. This new policy paradigm will hopefully persuade financial markets, analysts, and price-setters to raise their long-run inflation expectations back towards the 2 percent target, leading to a virtuous circle of lower average levels of slack, inflation expectations stable at target, and more monetary policy space.

\footnotetext{
22 The classic cases of rational expectations formation altering inflation in Sargent (1986) are all much more dramatic and easily understood regime shifts. Coibion and others (2018) suggest that households and firms are less responsive to news about inflation when it is at low levels.

${ }^{23}$ An average target leads to richer cyclical dynamics, with endogenous overshooting in the real economy, than a standard inflation target where policy aims bring the economy asymptotically to its equilibrium. Average inflation targets necessitate offsetting negative shocks to the economy with future positive output gaps to ensure a 2 percent average across the cycle.
} 


\section{REFERENCES}

Abrahams Michael, Tobias Adrian, Richard Crump, Emanuel Moench, and Rui Tu. 2016.

"Decomposing real and nominal yield curves." Journal of Monetary Economics, 84 (2016), pp. 182-200

Adrian, Tobias, Richard K. Crump, and Emanuel Moench, 2013. "Pricing the Term Structure with Linear Regressions," Journal of Financial Economics, Vol. 110, No. 1 (October): $110-38$

Aiyar, Shekhar and Simon Voigts. 2019. "The Negative Mean Output Gap.” Working Paper No. 19/183, International Monetary Fund, Washington D.C.

Bauer, Michael D. 2017. "Bridging the Gap: Forecasting Interest Rates with Macro Trends." FRBSF Economic Letter, Federal Reserve Bank of San Francisco, July 31.

Bauer, Michael D., and Glenn D. Rudebusch. 2017. "Interest Rates Under Falling Stars" Federal Reserve Bank of San Francisco Working Paper 2017-16.

Bernanke, Ben S., Michael T. Kiley, and John M. Roberts. 2019. "Monetary Policy Strategies for a Low-Rate Environment." AEA Papers and Proceedings, 109: 421-26.

Blanchard, Olivier. 2016. "The US Phillips Curve: Back to the 60s?” PIIE Policy Brief 16-1, Peterson Institute for International Economics, Washington, DC.

Böninghausen, Benjamin, Gregory Kidd and Rupert de Vincent-Humphreys. 2018. "Interpreting recent developments in market-based indicators of longer-term inflation expectations.” ECB Economic Bulletin, Issue 6/2018, European Central Bank.

Brainard, Lael. 2015. "Normalizing Monetary Policy When the Neutral Interest Rate Is Low." Speech at the Stanford Institute for Economic Policy Research, Stanford, California, December $1^{\text {st }}$.

Christensen, Jens H.E., Francis X. Diebold, and Glenn D. Rudebusch, "The Affine Arbitrage-Free Class of Nelson-Siegel Term Structure Models," Journal of Econometrics, September 2011, 164 (1), 4-20.

Chung, Hess; Etienne Gagnon, Taisuke Nakata, Matthias Paustian, Bernd Schlusche, James Trevino, Diego Vil'an, and Wei Zheng. 2019. "Monetary Policy Options at the Effective Lower Bound: Assessing the Federal Reserve's Current Policy Toolkit," Finance and Economics Discussion Series 2019-003. Washington: Board of Governors of the Federal Reserve System.

Clarida, Richard. 2019. "The Federal Reserve's Review of Its Monetary Policy Strategy, Tools, and Communication Practices." Speech at "Fed Policy: A Shadow Review" Cato Institute's 37th Annual Monetary Conference, Washington, D.C. 
Clark, Todd and Taeyoung Doh. 2014. "Evaluating alternative models of trend inflation." International Journal of Forecasting Volume 30, Issue 3, July-September 2014, Pages 426-448

Cochrane, John. 2007. “Commentary.” Federal Reserve Bank of St. Louis Review, July/August, p. 271-282

Coibion, Olivier; Yuriy Gorodnichenko; Saten Kumar; and Mathieu Pedemonte. 2018. "Inflation Expectations as a Policy Tool.” NBER working paper 24788.

Congressional Budget Office. 2015. "Why CBO Projects That Actual Output Will Be Below Potential Output on Average."

D’Amico, Stefania, Don Kim, and Min Wei. 2018. "Tips from TIPS: The Informational Content of Treasury Inflation-Protected Security Prices." Journal of Financial and Quantitative Analysis, 53(1), 395-436.

Dai, Qiang and Kenneth J. Singleton. 2002. "Expectation Puzzles, Time-Varying Risk Premia, And Affine Models Of The Term Structure," Journal of Financial Economics, vol. 63(3,Mar), 415-441.

Diebold, Francis X.; Rudebusch, Glenn D. and Aruoba, S. Boragan. 2005. "The Macroeconomy and the Yield Curve: A Dynamic Latent Factor Approach.” Journal of Econometrics, Volume 131, Issues 1-2, March-April 2006, Pages 309-338.

Dudley, William C., Jennifer E. Roush and Michelle Steinberg Ezer. 2008. "The Case for TIPS: An Examination of the Costs and Benefits." Staff Reports, Federal Reserve Bank of New York.

Duffee, Gregory. 2013. "Forecasting Interest Rates." Chapter 7 in Handbook of Economic 21 Forecasting, Vol. 2A, edited by Graham Elliott and Allan Timmermann. Amsterdam: Elsevier, pp. 385-426.

Faust, Jon and Jonathan Wright. 2013. "Forecasting Inflation" in Handbook of Economic Forecasting (G. Elliott and A. Timmermann (eds.)), Volume 2A, Elsevier.

Federal Reserve Board of Governors. 1996. "Transcript of the Meeting of the Federal Open Market Committee, July 2-3, 1996.” Washington, DC.

Fleckenstein, Matthias; Francis A. Longstaff, and Hanno Lustig 2010. "Why Does the Treasury Issue Tips? The Tips-Treasury Bond Puzzle.” NBER Working Paper No. 16358, September.

Fleischman, Charles A. and John M. Roberts. 2011. "From Many Series, One Cycle: 
Improved Estimates of the Business Cycle from a Multivariate Unobserved Components Model” Finance and Economics Discussion Series 2011-46, Federal Reserve Board of Governors.

Gagnon, Joseph and Christopher Collins. 2019. “Are Central Banks Out of Ammunition to Fight a Recession? Not Quite.” Policy Brief 19-18, Peterson Institute for International Economics, Washington DC, November.

General Accounting Office. 2009. "Debt Management: Treasury Inflation Protected Securities Should Play a Heightened Role in Addressing Debt Management Challenges." Report to the Secretary of the Treasury, September.

Guimarães, Rodrigo. 2014. "Expectations, risk premia and information spanning in dynamic term structure model estimation.” Working Paper No. 489, Bank of England, March.

Gürkaynak, Refet S., Brian Sack, and Jonathan H. Wright. 2010. "The TIPS Yield Curve and Inflation Compensation.” American Economic Journal: Macroeconomics 2 (1): 70-92. Updated data available at: https://www.federalreserve.gov/data/tips-yield-curve-andinflation-compensation.htm

Holston, Kathryn; Thomas Laubach; and John C. Williams. 2020. "Adapting the Laubach and Williams and Holston, Laubach, and Williams Models to the COVID-19 Pandemic" Federal Reserve Bank of New York. https://www.newyorkfed.org/research/policy/rstar

Ihrig, Jane; Elizabeth Klee, Canlin Li, Min Wei and Joe Kachovec, 2018. "Expectations about the Federal Reserve's Balance Sheet and the Term Structure of Interest Rates," International Journal of Central Banking, International Journal of Central Banking, vol. 14(2), pages 341-391, March.

Joslin, Scot; Kenneth J. Singleton; and Haoxiang Zhu. 2011. "A New Perspective on Gaussian Dynamic Term Structure Models.” The Review of Financial Studies, Volume 24, Issue 3, March, Pages 926-970,

Kamdar, Rupal. 2019. “The Inattentive Consumer: Sentiment and Expectations.” Working paper, December 9.

Kaminsky, Isabella. 2010. "The largest arbitrage ever documented.” The Financial Times, FT Alphaville blog, September $14^{\text {th }}$. https://ftalphaville.ft.com/2010/09/14/342286/thelargest-arbitrage-ever-documented/

Kim, Don. 2009. "Challenges in Macro-Finance Modeling.” Review, Federal Reserve Bank of St. Louis, 519-544. 
Kim, Don, and Jonathan Wright. 2005. "An Arbitrage-Free Three-Factor Term Structure Model and the Recent Behavior of Long Term Yields and Distant-Horizon Forward Rates." Finance and Economics Discussion Series Paper No. 2005-33, Board of Governors of the Federal Reserve System.

Kim, Don and Athanasios Orphanides. 2007. "The bond market term premium: what is it, and how can we measure it?" BIS Quarterly Review, Bank of International Settlements, June.

Kim, Don and Athanasios Orphanides. 2012. "Term Structure Estimation with Survey Data on Interest Rate Forecasts." Journal of Financial and Quantitative Analysis, 47, 241272.

Kumar, Saten; Hassan Afrouzi, Olivier Coibion, Yuriy Gorodnichenko, 2015. "Inflation Targeting Does Not Anchor Inflation Expectations: Evidence from Firms in New Zealand," Brookings Papers on Economic Activity, vol 2015(2), pages 151-225

Laubach, Thomas and John Williams. 2003. "Measuring the Natural Rate of Interest," Review of Economics and Statistics 85, no.4 (November): 1063-70.

Lumsdaine, Robin. 2009 “The Relationship Between Oil Prices and Breakeven Inflation Rates." December $29^{\text {th }}$. Available at SSRN: https://ssrn.com/abstract=1529487.

Plante, Michael D. and Kunal Patel. 2019. "Breakeven Oil Prices Underscore Shale's Impact on the Market." Dallas Fed Economics, Federal Reserve Bank of Dallas, May $21^{\text {st }}$.

Powell, Jerome. 2018. "Monetary Policy in a Changing Economy." Speech At "Changing Market Structure and Implications for Monetary Policy," a symposium sponsored by the Federal Reserve Bank of Kansas City, Jackson Hole, Wyoming, August $24^{\text {th }}$.

Rudebusch, G. R., and T. Wu, 2008, "A Macro-Finance Model of the Term Structure, Monetary Policy and the Economy," The Economic Journal, Vol. 118, pp. 906-926

Sack, Brian. 2007. “Are Long-Term Real Yields Now Attractive?” Inflation-Linked Analytics, Macroeconomic Advisers, June $28^{\text {th }}$.

Sack, Brian, and R. Elsasser. 2004. "Treasury Inflation-Indexed Debt: A Review of the U.S. Experience.” Economic Policy Review (Federal Reserve Bank of New York), 1047 63.

Sargent, Thomas. 1986. "The end of four big inflations." In Rational expectations and inflation, ed. Thomas Sargent, 40-109. New York: Harper and Row.

Summers, Lawrence. 2014. "U.S. Economic Prospects: Secular Stagnation, Hysteresis, and the Zero Lower Bound." Business Economics, National Association of Business Economists, Speech given on February 24. 
Thomas, Lloyd, B. 1999. "Survey Measures of Expected U.S. Inflation." Journal of Economic Perspectives, 13 (4): 125-144.

Vlieghe, Gertjan. 2018. "The yield curve and QE." Speech at Imperial College Business School, London, September $25^{\text {th }}$.

Williams, Peter; Yasser Abdih, and Emanuel Kopp. 2020. "Reading the stars." International Monetary Fund, IMF Working Paper No. 20/136.

https://www.imf.org/en/Publications/WP/Issues/2020/07/24/Reading-the-Stars-49599

Yellen, Janet. 2015. "Inflation Dynamics and Monetary Policy." Speech at the Philip Gamble Memorial Lecture, University of Massachusetts, Amherst, Amherst, Massachusetts, September $24^{\text {th }}$. 


\section{APPENDiX. ObSERVATION EQUATIONS}

The surveys help anchor the physical dynamics of the model we include economist surveys of inflation. For a given period ahead's forecast we iterate $K$ forward to generate the period approriate expectations. These have the same general form as the equation for $\pi_{t}^{12 m}$ but with different values in the second and third elements. The first is always 1 given the unit root assumption . For forcasts of average levels, we simply take the iterated factor weights over the relevant time horizon and average them. The parameter restrictions in the macroeconomic varaibles further serve to link the factors to the underlying economic phenomenon that drive inflation and it's risks. Demeaning the output gap has the effect of incorpating market and survey views about the long-run expected output gap into long-run expected inflation.

\begin{tabular}{|c|c|c|c|c|c|c|c|c|c|c|c|c|}
\hline & & & Unobserve & Tabl & le A1.1 & $\begin{array}{c}\text { Observ } \\
\text { Regression } \\
\text { series } \\
\end{array}$ & ion Equa & ons and & Data Sources & \multirow[b]{2}{*}{$\begin{array}{l}\text { Survey } \\
\text { respondents }\end{array}$} & \multirow[b]{2}{*}{ Frequency } & \multirow[b]{2}{*}{$\begin{array}{l}\text { Start } \\
\text { Date }\end{array}$} \\
\hline & & $\begin{array}{c}\text { Trend } \\
\text { inflation }\end{array}$ & $\begin{array}{c}\text { Business } \\
\text { cycle }\end{array}$ & $\begin{array}{c}\text { Oil } \\
\text { prices }\end{array}$ & Liquidity & $\begin{array}{l}\text { Moving avg. } \\
\text { of output } \\
\text { gap }\end{array}$ & $\begin{array}{c}\text { (convexity } \\
\text { adjustment, } \\
\text { x100) }\end{array}$ & $\begin{array}{c}\text { Measurement } \\
\text { error } \\
\text { (s.d., x100) }\end{array}$ & Source & & & \\
\hline & |12-month CPI & 1.000 & 1.000 & 1.000 & - & - & & 0.714 & Bureau of Labor Statistics & & Monthly & \\
\hline & Unemployment rate (demeaned & & 4.989 & & - & - & 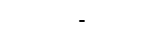 & 0 & Bureau of Labor Statistics & & Monthly & \\
\hline & 12-month change in oil prices & - & - & 49.36 & & - & - & 0 & EIA/Chicago Mercantile Exchange & & Monthly & \\
\hline & 2-year TIPS Breakevens & 1.090 & 0.516 & 0.180 & $(0.075)$ & - & -0.103212093 & 0.498 & Gurkynak, Sack, and Wright (2008) & & Monthly & 1999 \\
\hline & 5-year TIPS Breakevens & 1.254 & 0.254 & 0.072 & $(0.071)$ & - & -0.358463818 & 0.080 & Gurkynak, Sack, and Wright (2008) & & Monthly & 1999 \\
\hline & 7-year TIPS Breakevens & 1.381 & 0.184 & 0.051 & $(0.055)$ & - & -0.520827166 & 0.000 & Gurkynak, Sack, and Wright (2008) & & Monthly & 1999 \\
\hline & 10-year TIPS Breakevens & 1.604 & 0.129 & 0.036 & $(0.041)$ & - & -0.755358233 & 0.059 & Gurkynak, Sack, and Wright (2008) & & Monthly & 1999 \\
\hline & 15-year TIPS Breakevens & 2.084 & 0.086 & 0.024 & $(0.030)$ & - & -1.225750861 & 0.071 & Gurkynak, Sack, and Wright (2008) & & Monthly & 1999 \\
\hline & 20-year TIPS Breakevens & 2.748 & 0.065 & 0.018 & $(0.025)$ & - & -1.989879645 & 0.133 & Gurkynak, Sack, and Wright (2008) & & Monthly & 1999 \\
\hline \multirow{12}{*}{ 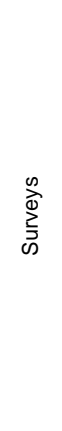 } & 1-quarter ahead SPF survey & 1.000 & 0.827 & 0.251 & - & - & - & 0.319 & Federal Reserve Bank of Philadelphia & Economists & Quarterly & \\
\hline & 2-quarter ahead SPF survey & 1.000 & 0.739 & 0.110 & - & - & - & 0.217 & Federal Reserve Bank of Philadelphia & Economists & Quarterly & \\
\hline & 3-quarter ahead SPF survey & 1.000 & 0.659 & 0.048 & - & - & - & 0.175 & Federal Reserve Bank of Philadelphia & Economists & Quarterly & \\
\hline & 4-quarter ahead SPF survey & 1.000 & 0.588 & 0.021 & - & - & - & 0.179 & Federal Reserve Bank of Philadelphia & Economists & Quarterly & \\
\hline & 10-year average SPF survey & 1.000 & & & - & -4.989 & - & 0.198 & Federal Reserve Bank of Philadelphia & Economists & Quarterly & \\
\hline & 5-year forward 5-year average & 1.000 & - & - & - & -4.989 & - & 0.260 & Consensus Economics & Economists & Bi-annual/quarterly & \\
\hline & $\begin{array}{l}\text { 10-year average Survey of } \\
\text { Primary Deealers }\end{array}$ & 1.000 & 0.214 & 0.026 & & & & 0.103 & Federal Reserve Bank of New York & Economists & 8 times per year & 2011 \\
\hline & $\begin{array}{l}\text { 10-year average Survey of } \\
\text { Market Participants }\end{array}$ & 1.000 & 0.214 & 0.026 & & & & 0.045 & Federal Reserve Bank of New York & Buy-side Firms & s 8 times per year & 2015 \\
\hline & 1-year average consumer & 1.000 & $\begin{array}{l}0.788 \\
0.387\end{array}$ & 0.253 & - & - & & $\begin{array}{l}0.646 \\
0.228\end{array}$ & University of Michigan & Consumers & Monthly & \\
\hline & $\begin{array}{l}\text { 5-year average consumer } \\
1 \text {-year lagged unit costs }\end{array}$ & 1.000 & 0.635 & $\begin{array}{l}0.052 \\
0.036\end{array}$ & . & - & - & $\begin{array}{l}0.228 \\
0.105\end{array}$ & $\begin{array}{l}\text { University of Michigan } \\
\text { Federal Reserve Bank of Atlanta }\end{array}$ & $\begin{array}{l}\text { Consumers } \\
\text { Businesses }\end{array}$ & $\begin{array}{l}\text { Moonthiy } \\
\text { Monthly }\end{array}$ & 2011 \\
\hline & $\begin{array}{l}1 \text {-year lagged unit costs } \\
1 \text {-year ahead unit costs }\end{array}$ & 1.000 & 0.635 & 0.036 & - & - & - & 0.250 & Federal Reserve Bank of Atlanta & Businesses & Monthly & 2011 \\
\hline & 1-year ahead inflation - CFOs & 1.000 & 0.635 & 0.036 & - & - & - & 0.164 & Duke University & CFOs & Quarterly & \\
\hline
\end{tabular}

